Gut, 1975, 16, 774-776

\title{
The role of the antrum in determining the acid secretory response to meals of different consistency
}

\author{
D. R. HUNT ${ }^{1}$ AND A. P. M. FORREST \\ From the Welsh National School of Medicine and United Cardiff Hospitals, Cardiff
}

SUMMARY Three dogs with denervated pouches of stomach were tested with two test meals, one of homogenized and the other of minced meat, before and after antral denervation. The results show that the preparation of food plays an important part in the acid response and that homogenization augments acid stimulatory potential, probably by virtue of increased buffer capacity.

Krzyshovski, in 1906 (quoted by Babkin, 1950), reported that meat fed to dogs in fine particulate form stimulated a weaker secretory response by the stomach than the same amount of meat given as large lumps. Since that time, patients with peptic ulcers have been prescribed, on the advice of Sippy, soft, bland diets in the belief that this consistency of food will stimulate less acid secretion from the stomach than food of normal consistency (Sippy, 1915). More recent evidence (Buchman, Kaung, Dolan, and Knapp, 1969; Doll, Friedlander, and Piggott, 1956) has disputed the value of such diets in ulcer patients and it appeared reasonable to re-examine the influence of the consistency of a meal on antral function.

The present study was designed to assess the secretory response to meat in homogenized and minced forms given to dogs with denervated pouches. To determine the importance of antral innervation in the responses to these two feeds, tests were repeated after antral denervation.

\section{Methods}

Three dogs with Heidenhain pouches were prepared and, after a recovery period of three weeks, meal tests were carried out. Each dog was tested on five separate occasions with each of the two meals. When control studies were complete antral denervation was performed in situ, as previously described, by a technique of combined neurovascular clearance and circumferential myotomy (Hunt, 1972). Three weeks later the programme of meal tests was repeated.

${ }^{1}$ Address for reprints: Department of Surgery, St. George Hospital, Kogarah, 2217 NSW, Australia.

Received for publication 9 July 1975.
All the meat for the two test meals was prepared at the outset of the study. Frozen ox hearts were thawed, defatted, then minced to approximately $0.5 \mathrm{~cm}$ pieces. Half of this minced meat was then refrozen in $400 \mathrm{~g}$ containers for use as the minced ox heart meal. The remainder was homogenized after the addition of $20 \%$ by weight of water, the water being required to produce a meal of comparable viscosity. This preparation was similarly stored for use as the homogenized ox heart meal. Test meals were given on a body weight basis after overnight thawing. For minced meat, $15 \mathrm{~g} / \mathrm{kg}$ was given whilst for homogenized meat $18 \mathrm{~g} / \mathrm{kg}$ was used. The difference in these two values provided correction for the added water in the latter and presented meals of equal protein content.

The acid output from the pouch was measured every 15 minutes for four hours after feeding. The results were analysed on a group basis by comparing the means of the logarithms of the four-hour output of acid $(\times 100)$ for each meal at each stage by an analysis of variance.

The physico-chemical characteristics of these feeds were assessed in two studies. In the first of these, the buffering capacity of equal portions, by weight of protein, was compared. Secondly, the effect of homogenization on the free amino acid content was measured. The supernatant obtained after centri fugation of similar portions of each feed mixed with saline was subjected to gas-column chromatography for free amino acids (Technicon AutoAnalyzer, Department of Biochemistry, Singleton Hospital, Swansea, UK).

\section{Results}

In each dog, the mean acid output after feeding with 774 


\begin{tabular}{|c|c|c|c|c|c|c|c|c|c|c|c|c|c|}
\hline \multirow{3}{*}{$\begin{array}{l}\text { Dog } \\
\mathbf{A}\end{array}$} & \multirow{3}{*}{$\begin{array}{l}\text { Test Meal } \\
\text { Minced } \\
\text { Homogenized }\end{array}$} & \multirow{2}{*}{\multicolumn{5}{|c|}{$\frac{\text { Control }}{\text { Acid Output }}$}} & \multicolumn{6}{|c|}{ Antral Denervation } & \multirow{3}{*}{$\begin{array}{c}\text { Mean } \\
0.97 \\
1.13\end{array}$} \\
\hline & & & & & & & \multirow{2}{*}{$\begin{array}{l}\text { Mean } \\
0.67 \\
1.13\end{array}$} & \multicolumn{5}{|c|}{ Acid Output } & \\
\hline & & $\begin{array}{l}1.06 \\
0.79\end{array}$ & $\begin{array}{l}0.68 \\
1 \cdot 36\end{array}$ & $\begin{array}{l}0 \cdot 46 \\
1 \cdot 74\end{array}$ & $\begin{array}{l}0.44 \\
1.06\end{array}$ & $\begin{array}{l}0.73 \\
0.73\end{array}$ & & $\begin{array}{l}0.62 \\
1 \cdot 35\end{array}$ & $\begin{array}{l}0.76 \\
0.82\end{array}$ & $\begin{array}{l}0.97 \\
1 \cdot 12\end{array}$ & $\begin{array}{l}1 \cdot 30 \\
1 \cdot 17\end{array}$ & $\begin{array}{l}0.66 \\
1 \cdot 18\end{array}$ & \\
\hline $\mathbf{B}$ & $\begin{array}{l}\text { Minced } \\
\text { Homogenized }\end{array}$ & $\begin{array}{l}1 \cdot 14 \\
3 \cdot 72\end{array}$ & $\begin{array}{l}1 \cdot 10 \\
2 \cdot 32\end{array}$ & $\begin{array}{l}2 \cdot 07 \\
2 \cdot 68\end{array}$ & $\begin{array}{l}2 \cdot 23 \\
2 \cdot 27\end{array}$ & $\begin{array}{l}1 \cdot 90 \\
2 \cdot 10\end{array}$ & $\begin{array}{l}1 \cdot 69 \\
2.62\end{array}$ & $\begin{array}{l}0.52 \\
0.55\end{array}$ & $\begin{array}{l}0.97 \\
1.23\end{array}$ & $\begin{array}{l}1 \cdot 28 \\
1 \cdot 21\end{array}$ & $\begin{array}{l}0.82 \\
1.69\end{array}$ & $\begin{array}{l}1 \cdot 14 \\
1 \cdot 10\end{array}$ & $\begin{array}{l}0.94 \\
1 \cdot 16\end{array}$ \\
\hline $\mathbf{C}$ & $\begin{array}{l}\text { Minced } \\
\text { Homogenized }\end{array}$ & $\begin{array}{l}6 \cdot 05 \\
7 \cdot 98\end{array}$ & $\begin{array}{r}6 \cdot 18 \\
10 \cdot 08\end{array}$ & $\begin{array}{l}6 \cdot 95 \\
8 \cdot 80\end{array}$ & $\begin{array}{l}6 \cdot 49 \\
8 \cdot 55\end{array}$ & $\begin{array}{l}6 \cdot 83 \\
9 \cdot 73\end{array}$ & $\begin{array}{l}6 \cdot 50 \\
9 \cdot 03\end{array}$ & $\begin{array}{l}3 \cdot 22 \\
1 \cdot 75\end{array}$ & $\begin{array}{l}3 \cdot 58 \\
3 \cdot 84\end{array}$ & $\begin{array}{l}3 \cdot 95 \\
2 \cdot 85\end{array}$ & $\begin{array}{l}2 \cdot 62 \\
3 \cdot 87\end{array}$ & $\begin{array}{l}4 \cdot 71 \\
4 \cdot 90\end{array}$ & $\begin{array}{l}3 \cdot 62 \\
3 \cdot 44\end{array}$ \\
\hline
\end{tabular}

Table I Four-hour outputs of acid in mmol $\mathrm{HCl}$ after feeding two test feeds to three dogs with denervated pouches before and after antral denervation

\begin{tabular}{|c|c|c|c|c|}
\hline & Control & $\begin{array}{l}\text { Antral } \\
\text { Denervation }\end{array}$ & $\boldsymbol{F}$ & $\mathbf{P}$ \\
\hline $\begin{array}{l}\text { Minced meat } \\
\text { Homogenized } \\
\text { meat }\end{array}$ & $\begin{array}{l}2 \cdot 2750 \\
2 \cdot 4645\end{array}$ & $\begin{array}{l}2 \cdot 1428 \\
2 \cdot 1990\end{array}$ & $\begin{array}{r}5.63 \\
10.09\end{array}$ & $\begin{array}{l}<0.05 \\
<0.01\end{array}$ \\
\hline $\begin{array}{l}\mathbf{F} \\
\mathbf{P}\end{array}$ & $\begin{array}{l}-27.8 \\
>0.001\end{array}$ & $\begin{array}{l}-1.23 \\
<0.1\end{array}$ & & \\
\hline
\end{tabular}

Table II Results of comparisons by analysis of variance between mean log acid outputs $(\times 100)$ to two feeds before and after antral denervation

homogenized meat exceeded that for minced ox heart. On group analysis this difference was highly significant (tables I and II).

Antral denervation reduced the acid response to both meals in two of the dogs. The third was unchanged but, for the group, the reduction in the mean was significant. The decrease was more marked for the homogenized meal and there was no longer a difference between the responses to the two meals after denervation (tables I and II).

The titration curves (see fig) show that when particle size is reduced, the buffering capacity is

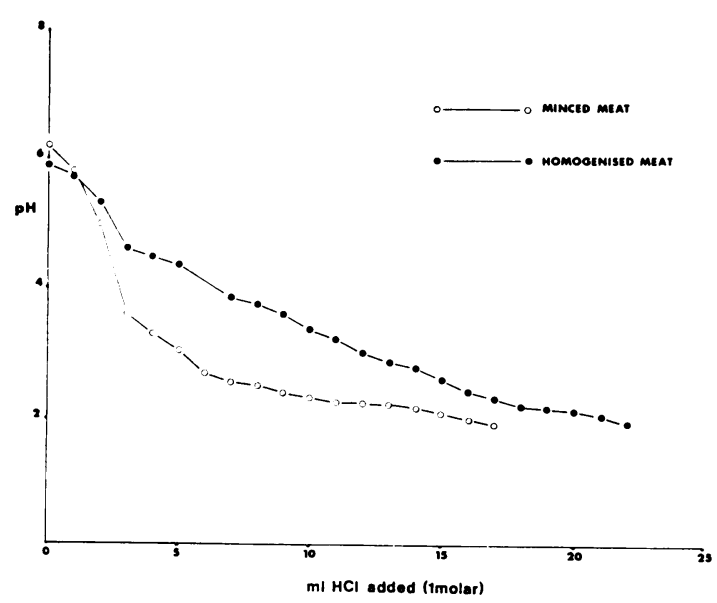

Fig Titration curves of aliquots of each feed containing $50 \mathrm{~g}$ of meat protein with 1 molar $\mathrm{HCl}$. increased. This increase cannot be explained on the basis of release of free amino acids since that analysis showed (with the exception of threonine) little difference between the feeds. Furthermore, only minor differences in concentration were observed for the short chain $(\mathrm{C}-2,3)$ amino acids which produce chemical stimulation of the antrum ${ }^{1}$.

\section{Discussion}

In a previous study (Hunt, 1972) we confirmed the finding of Williams, Forrest, and Campbell (1968) that the acid output from a denervated pouch is related to the buffering capacity of the meal. In the present study there was little change in the biochemical characteristics of the meal after homogenization and the increased acid response to meat after this treatment might also be attributed to its increased buffer capacity.

However, our findings are at variance with earlier work which showed that lumps of meat produced more acid than did meat in particulate form. This difference is difficult to explain but, from the description given by Babkin, it appears that fairly large lumps of meat were used and these may have caused additional gastrin release by antral distension. It must also be pointed out that those tests were done in different dogs and it is not even certain that the same weight or approximate bulk of food was given.

Whilst these results cannot be extrapolated to man, they do challenge the original basis for the introduction of the Sippy diet and indicate the need for reviewing the effects of the preparation of food on acid secretion in man.

The reduction in acid output after antral denervation is similar to that seen in our earlier study (Hunt, 1972). However, in that study, using potato meals of different buffering capacity, the buffered potato meal continued to evoke a more powerful secretory response than plain potato after antral

IValues for amino acid concentrations are available on request from the authors. 
denervation. Why the advantage of homogenized meat over minced meat was lost after denervation cannot be answered from this study. Alterations in emptying from a denervated antrum would be more likely to affect the different meat meals than the physically similar potato meals. After denervation, the minced meat may have been retained in the antrum for a longer period, exerting more prolonged stimulation than the homogenized meat. It might be suggested that the greater acid output with the homogenized meat resulted from release of more gastrin by vagal action and this effect of palatability was lost after denervation. If anything, the dogs ate the homogenized meat with less relish than for the minced meat so that this explanation appears unlikely.

\section{References}

Babkin, B. P. (1950). Secretory mechanisms of the digestive glands. 2nd ed. P. Hoeber, New York.

Buchman, E., Kaung, D. I., Dolan, K., and Knapp, R. D. (1969) Unrestricted diet in the treatment of duodenal ulcer. Gastroenterology, 56, 1016-1020.

Doll, R., Friedlander, P., and Pygott, F. (1956). Dietetic treatment of peptic ulcer. Lancet, 1, 5-8.

Hunt, D. R. (1972). Vagal influence on canine gastric antrum. MD Thesis, University of Sydney.

Sippy, B. W. (1915). Gastric and duodenal ulcer. J. Amer. med. Ass., 64, 1625-1630.

Williams, C. B., Forrest, A. P. M., and Campbell, H. (1968). Buffering capacity of food in relation to stimulation of gastric secretion. Gastroenterology, 55, 567-574. 